\title{
Status of Learning Facilities for Primary School Physics Curriculum Implementation in Eastern Ethiopia
}

\author{
Kemal Abdulbasit ${ }^{1}$, Yilfashewa Seyoum²
}

Article History:
Received 16.07.2020
Received in revised
form 16.03.2021
Accepted
Available online
01.07.2021

Article History:

Received 16.07.2020

form 16.03.2021

Accepted

01.07.2021

\begin{abstract}
The aim of this study is to examine the status of learning facilities for primary school physics curriculum implementation in Harari Region, Eastern Ethiopia. A survey design and a mixed approach were used to deliberate the study. Stratified and purposive sampling techniques were employed to select respondents (317 students, 12 cluster supervisors, 34 physics teachers and 34 principals). Quantitative and Qualitative data were obtained through questionnaire, interview guide, and observation checklist and document analysis. Descriptive statistics and independent sample t-test were used as a means for data analysis. The findings revealed that the status of learning facilities for physics curriculum implementation was inadequate in the region. There exists no significant difference between urban and rural schools on the availability of learning facilities (availability of learning facilities for urban and rural schools are corresponding). It was concluded that due attention was given to both urban and rural schools. However, the inadequacy in availability of learning facilities results in ineffective implementation of physics curriculum in the region. Therefore, collaborative efforts need to put in place among government, NGOs and the community to improve status of learning facilities for physics curriculum implementation in all schools.
\end{abstract}

(C) IJERE. All rights reserved

\section{Keywords: ${ }^{1}$}

Curriculum implementation, learning facilities, physics curriculum, primary school, Harari region.

\section{INTRODUCTION}

Education is the safe way to help people improve their knowledge and experiences. Education is an essential pathway to make a responsible nation and in this the various resources provided play a crucial role (Dayo et al., 2013). This means that for education to effectively take place it demands adequate availability and proper utilization of educational facilities. In other words, through education, people can develop their understanding of themselves and the real world. Science is generally considered as the study of facts related to natural and material world. Modern era; however, has brought a shift in the views about science education from objective fact-based knowledge to practical activity which caters to the learners' skills, attitude, and values along with understanding (Donnelly \& Jenkins, 2001). It is as a result of the recognition given to physical sciences in the development of the individual and the nation that science subjects (biology, chemistry and physics) are considered core subjects among the natural sciences and other science related courses in the Ethiopian education system. The inclusion of these subjects as core subjects in science in the schools calls for the need to teach them effectively (Negassa, 2014). Thus, for effective teaching and learning of science subjects the importance of learning facilities needs to be well considered.

Physics is an important subject for economic, scientific and technological development (Zhaoyao, 2002). It is a practical subject where a systematic approach to studying phenomena, including careful observation, accurate measurement and careful experimentation is used. According to Oladejo et al (2011) mastery of physics concepts cannot be fully achieved without the use of instructional materials. Instructional materials are used to supplement verbal explanation of concepts or any description so that the lesson could be real to the students. The absence of these materials in teaching of physics could make the class tedious to student and discourage learning thereby led to low or poor achievement. Thus, to enhance learning and attain the desired output the implementation of science education in general and physics in particular requires educational facilities or resources (human, material and physical) that improve teaching/learning processes. Educational environments are usually established for the purpose of teaching and learning. This purpose may however

'kembasit@gmail.com, Haramaya University, orcid.org/0000-0002-5107-1736 ${ }^{2}$ yilfa2014@gmail.com, Haramaya University, orcid.org/0000-0002-0825-7340 
not be achieved when the constituting components of educational environments like school buildings, library facilities, furniture items, instructional materials, lighting, and so on, are either not available, inadequate or properly structured and organized (Akomaye \& Paulina, 2017). According to Murungi et al (2018), learning environment consists of many factors such as teaching and learning materials such as text books and charts and physical facilities such as classrooms, library, resting rooms, and playground among others. The existence and conditions of learning facilities also determine the extent to which a physics curriculum is implemented. According to Bandele \& Faremi (2012); Umunadi (2012); Tshabalala \& Ncube (2014), relevant equipment, materials and tools such as laboratories, lecture rooms and reference texts are required in the teaching and learning process to yield the intended educational outputs. That is, quality education hinges on physical facilities that are the ultimate predictors of students' academic achievements (Yara \& Otieno, 2010; Moochi, 2012). As many studies revealed practical work cannot be taken place without having the necessary equipment, apparatus and reagents in the school laboratory (Bekalo and Welford, 2000). Therefore, lack of materials and other facilities highly restrict students to perform practical works in the laboratory and demonstrations and other practical activities in the classroom or in the field. That is adequacy of facilities and laboratory equipment's are necessary for proper implementation of physics curriculum. Students' achievement at any point is a cumulative function of inputs such as laboratories, textbooks, school buildings and libraries (Dahar et al., 2009). Provision of stationery and teaching aids is also critical to curriculum implementation. According to Yara and Otieno (2010), the more the provision of stationeries and teaching aids the better the academic performance of students. The findings of Yadar (2001) and the Report by UNESCO (2008) have shown that classrooms, teaching aids and stationery affect the academic performance of learners. Further, they argue that learning is strengthened when there are enough reference materials such as textbooks and classrooms. Ethiopia has made significant progress in education. Access at all levels of the education system increased at a rapid rate in line with a sharp increase in the number of teachers, schools and institutions. There were important improvements in the availability of trained teachers and some other inputs which are indispensable for a high-quality education system (MoE, 2010). As to Ethiopian Ministry of Education (2002) to ensure the quality of education, students should have quality textbooks, instructional materials and other school facilities in sufficient quantity and quality. According to Kimberly et al (2009) improving science and mathematics learning is of great concern to educators and policy makers. Because early experiences affect later education outcomes, providing young children with research-based science and mathematics learning opportunities is likely to pay off with increased achievement, literacy, and work skills in these critical areas. The above research findings indicated that the focus of many researchers was on uses of instructional materials, laboratory/practical work and effects of physical facilities on students' academic achievement. However, the present study intended to assess the status of learning facilities for physics curriculum implementation in primary schools of Harari region. The following basic research questions were posed to guide the present study:

(1) To what extent learning facilities were provided in the implementation of primary school physics curriculum in Harari region?

(2) Is there any significant difference between urban and rural schools regarding availability of learning facilities for the implementation of primary school physics curriculum in Harari region?

\section{METHOD}

The study employed a survey design that involves qualitative and quantitative research approaches (mixed research approach). According to Best and Khan (2005), survey involves acquiring information about one or more group of people, asking them questions and tabulating their answers. The ultimate goal of a survey research design is to learn about a large population by surveying their representative sample, summarizing their responses in percentages, frequency, as well as with more sophisticated statistical methods (Sarantakos, 2005). Survey helps to identify the major practice, opinions, suggestions and comments pertaining to the issue under study.

Grade 7 and 8 students, physics teachers and their respective school principals and vice principals in the selected schools were the population of this study. 349 students were taken as a sample by stratified random sampling techniques using a single population proportion formula. 34 physics teachers, 34 principals, and 12 cluster supervisors were included in the sample using purposive sampling techniques. The characterictics of participants are presented in Table 1 bellow.

Table 1. Participant of the study 


\begin{tabular}{lccccc}
\hline & Students & $\begin{array}{c}\text { Physics } \\
\text { Teachers }\end{array}$ & Principals & $\begin{array}{c}\text { Cluster } \\
\text { Supervisors }\end{array}$ \\
\hline \multirow{4}{*}{ Age in Years } & $<13$ & 10 & -- & -- & -- \\
& $13-15$ & 302 & -- & -- & -- \\
& $>15$ & 37 & -- & -- & -- \\
& $25-30$ & -- & 9 & 4 & -- \\
& $31-35$ & -- & 14 & 7 & 3 \\
Gender & $36-40$ & -- & 8 & 17 & 5 \\
& $>40$ & -- & 3 & 6 & 4 \\
Educational & Total & 349 & 34 & 34 & 12 \\
Level & Male & 206 & 33 & 17 & 1 \\
& Female & 143 & 1 & 17 & 12 \\
& Total & 349 & 34 & -- & - \\
& Grade 7 & 140 & -- & -- & -- \\
& Grade 8 & 209 & -- & -- & 12 \\
& Diploma & -- & 14 & 34 & 12 \\
\hline
\end{tabular}

Questionnaire, semi-structured interview, observation and document analysis were used for data collection. Content validity of the items was checked by the subject experts in the College of Education and Behavioural Sciences at Haramaya University. Internal-reliability coefficients were computed for the items based on the pilot data from schools which were not included in the main study. The pilot study results are presented in Table 2.

Table 2. Result of pilot test of questionnaire for test of reliability

\begin{tabular}{|c|c|}
\hline Respondents & Cronbach alpha \\
\hline Students & 0.704 \\
\hline Physics Teachers & 0.791 \\
\hline Principals & 0.846 \\
\hline & 0.780 \\
\hline
\end{tabular}

According to Gay and Airasian criteria for accepting a research tool, the reliability coefficient should attain greater or equal to 0.7 (Gay \& Airasian, 2003). Hence, the above table clearly indicates that the reliability score was 0.78 and this assures that the instrument was reliable to use for the actual data gathering activity and it was used. Descriptive statistics such as mean, grand mean, standard deviation and inferential statistics such as independent sample t-test was used for data analysis.

\section{RESULTS}

This section deals with the presentation and analysis of data gathered from groups of respondents. The questionnaire was distributed to 417 respondents. Out of these questionnaires 385 (92.3\%) were filled out, returned and used for the quantitative data analysis. The interview responses, observation and document analysis results were presented in narrative format. The mean score $(\bar{x})$ and the standard deviation (SD) of each item have been included to shed light on the first basic question. This research question was concerned with the status of learning facilities for primary school physics curriculum implementation as alleged by the physics teachers, principals and students (Table 3 and 4). 
Table 3. Results of group statistics for Physics Teachers and Principals

\begin{tabular}{|c|c|c|c|c|c|c|}
\hline \multirow{3}{*}{$\begin{array}{l}\text { Items } \\
\text { Textbooks }\end{array}$} & \multicolumn{6}{|c|}{ Types of Respondents } \\
\hline & \multicolumn{2}{|c|}{ Physics Teachers } & \multicolumn{2}{|c|}{ Principals } & \multicolumn{2}{|c|}{ Total } \\
\hline & $\mathrm{N}$ & 34 & $\mathrm{~N}$ & 34 & $\mathrm{~N}$ & 68 \\
\hline & Mean & 2.44 & Mean & 2.59 & Mean & 2.52 \\
\hline \multirow{4}{*}{ Teachers guide } & $\mathrm{SD}$ & .705 & SD & .657 & $\mathrm{SD}$ & .680 \\
\hline & $\mathrm{N}$ & 34 & $\mathrm{~N}$ & 34 & $\mathrm{~N}$ & 68 \\
\hline & Mean & 1.88 & Mean & 1.82 & Mean & 1.85 \\
\hline & SD & .478 & SD & .626 & SD & .554 \\
\hline \multirow{3}{*}{ Syllabus } & $\mathrm{N}$ & 34 & $\mathrm{~N}$ & 34 & $\mathrm{~N}$ & 68 \\
\hline & Mean & 1.68 & Mean & 1.50 & Mean & 1.59 \\
\hline & SD & .638 & SD & .615 & SD & .628 \\
\hline \multirow[t]{3}{*}{ Teaching aid } & $\mathrm{N}$ & 34 & $\mathrm{~N}$ & 34 & $\mathrm{~N}$ & 68 \\
\hline & Mean & 1.82 & Mean & 1.76 & Mean & 1.79 \\
\hline & $\mathrm{SD}$ & .673 & SD & .654 & $\mathrm{SD}$ & .659 \\
\hline \multirow[t]{3}{*}{ Reference books } & $\mathrm{N}$ & 34 & $\mathrm{~N}$ & 34 & $\mathrm{~N}$ & 68 \\
\hline & Mean & 2.06 & Mean & 2.24 & Mean & 2.15 \\
\hline & $\mathrm{SD}$ & .547 & $\mathrm{SD}$ & .740 & $\mathrm{SD}$ & .652 \\
\hline \multirow[t]{3}{*}{ Laboratory Manuals } & $\mathrm{N}$ & 34 & $\mathrm{~N}$ & 34 & $\mathrm{~N}$ & 68 \\
\hline & Mean & 1.35 & Mean & 1.12 & Mean & 1.24 \\
\hline & SD & .597 & SD & .327 & SD & .492 \\
\hline \multirow[t]{3}{*}{ Laboratory Equipment } & $\mathrm{N}$ & 34 & $\mathrm{~N}$ & 34 & $\mathrm{~N}$ & 68 \\
\hline & Mean & 2.41 & Mean & 2.38 & Mean & 2.39 \\
\hline & $\mathrm{SD}$ & .499 & $\mathrm{SD}$ & .493 & $\mathrm{SD}$ & .492 \\
\hline \multirow[t]{3}{*}{ LaboratoryTechnician } & $\mathrm{N}$ & 34 & $\mathrm{~N}$ & 34 & $\mathrm{~N}$ & 68 \\
\hline & Mean & 1.00 & Mean & 1.00 & Mean & 1.00 \\
\hline & SD & .000 & SD & .000 & $\mathrm{SD}$ & .000 \\
\hline \multirow[t]{3}{*}{ Library Room } & $\mathrm{N}$ & 34 & $\mathrm{~N}$ & 34 & $\mathrm{~N}$ & 68 \\
\hline & Mean & 1.97 & Mean & 1.82 & Mean & 1.89 \\
\hline & SD & .674 & SD & .626 & SD & .649 \\
\hline \multirow[t]{3}{*}{ Laboratory Room } & $\mathrm{N}$ & 34 & $\mathrm{~N}$ & 34 & $\mathrm{~N}$ & 68 \\
\hline & Mean & 1.94 & Mean & 2.06 & Mean & 2.00 \\
\hline & SD & .600 & SD & .600 & $\mathrm{SD}$ & .598 \\
\hline \multirow[t]{3}{*}{ Pedagogical Center } & $\mathrm{N}$ & 34 & $\mathrm{~N}$ & 34 & $\mathrm{~N}$ & 68 \\
\hline & Mean & 1.76 & Mean & 1.88 & Mean & 1.82 \\
\hline & SD & .606 & SD & .640 & $\mathrm{SD}$ & .621 \\
\hline
\end{tabular}

Level of Agreement: [(1.00 - 1.66 = not available); $(1.67-2.32=$ poor $)$ and $(2.33-3.00=$ good $)]$

As Table 3 depicts, the availability status of text books $(\bar{x}=2.52)$ were good while the availability status of teachers guide $(\bar{x}=1.85)$ were poor. On the other hand, regarding the availability status of syllabus in the schools the mean value is $(\bar{x}=1.59)$ showing that syllabus is not available in those schools. Additionally, the interview held with cluster supervisors confirmed that there are shortage of teachers guide and absence of syllabus in their schools. Moreover, regarding the availability status of teaching aid and reference books the mean values are $(\bar{x}=1.79)$ and $(\bar{x}=2.15)$ respectively showing that the availability status of teaching aid and reference books are poor. Whereas, with respect to the availability status of laboratory manuals the mean value is $(\bar{x}=1.24)$ showing that laboratory manuals are not available in those schools. On the other hand, the availability status of laboratory equipment $(\bar{x}=2.39)$ were good. Most of the cluster supervisors' interviewees responded that "very few teachers prepare and use teaching aids, there is shortage of appropriate reference books in the library and there is no formally developed laboratory manual rather there is an attempt of preparing by very few teachers". Moreover, from document analysis and school observation it is revealed that for all schools physics laboratory 
equipment's are distributed and are available at all schools. Also, from the above Table 3, it can be seen that concerning the availability status of laboratory technician the mean value is $(\bar{x}=1.00)$ showing that laboratory technician were not available in those schools. During the interview many cluster supervisors forwarded their views that "there was no laboratory technician in all primary schools and this affects the practical activities to be conducted in laboratory". However, with respect to the availability status of library room, laboratory room and pedagogical center the mean values are $(\bar{x}=1.89),(\bar{x}=2.00)$ and $(\bar{x}=1.82)$ respectively showing that the availability status of library room, laboratory room and pedagogical center are poor. Moreover, from the observations made in all schools it is seen that all schools have library room, laboratory room and pedagogical centers but in most of the schools there is one laboratory room for all science subjects (Biology, Chemistry and Physics). Additionally, the laboratory rooms are not well furnished rather there are ordinary office furniture in the laboratory rooms, equipment's are not well organized and there are full of dusts on them indicating that most of the equipment's are not utilized for practical activities. Library rooms are also narrow in space and in some schools pedagogical centers are also used as store for different materials.

Table 4. Results of statistics for students' respondents $(n=317)$

\begin{tabular}{lccccccc}
\hline \multicolumn{1}{c}{ Items } & \multicolumn{1}{c}{ f } & \multicolumn{2}{c}{2} & \multicolumn{2}{c}{3} & Mean $(\bar{x})$ \\
\hline Textbooks & $\mathrm{f}$ & $\%$ & $\mathrm{f}$ & $\%$ & $\mathrm{f}$ & $\%$ & 2.75 \\
Teaching aid & 21 & 6.6 & 36 & 11.4 & 260 & 82 & 1.85 \\
Reference books & 59 & 18.6 & 248 & 78.2 & 10 & 3.2 & 2.03 \\
Laboratory manuals & 21 & 6.6 & 265 & 83.6 & 31 & 9.8 & 1.17 \\
Laboratory equipment & 277 & 87.4 & 26 & 8.2 & 14 & 4.4 & 2.01 \\
Laboratory technician & 57 & 18 & 199 & 62.8 & 61 & 19.2 & 1.24 \\
Library room & 265 & 83.6 & 28 & 8.8 & 24 & 7.6 & 1.82 \\
Laboratory room & 75 & 23.7 & 223 & 70.3 & 19 & 6.0 & 1.86 \\
\hline
\end{tabular}

${ }^{*}$ Rating Scales, 1 = Not Available, 2 = Inadequate and $3=$ Adequate, ${ }^{*} \mathrm{f}=$ frequency

Level of Agreement: [(1.00 - 1.66 = not available); $(1.67-2.32=$ poor $)$ and $(2.33-3.00=$ good $)]$

Table 4 discloses that, the availability status of text books $(\bar{x}=2.75)$ were good. While the availability status of teaching aid and reference books with mean value $(\bar{x}=1.85)$ and $(\bar{x}=2.03)$ respectively were poor. Whereas, with respect to the availability status of laboratory manuals the mean value is $(\bar{x}=1.17)$ showing that laboratory manuals are not available in those schools. On the other hand, the availability status of laboratory equipment $(\bar{x}=2.01)$ were poor. Whereas, concerning the availability status of laboratory technician the mean value is $(\bar{x}=1.24)$ showing that laboratory technician were not available in those schools. However, with respect to the availability status of library room and laboratory room the mean values are $(\bar{x}=1.82)$ and $(\bar{x}=$ 1.86) respectively showing that the availability status of library room and laboratory room are poor.

Table 5. Independent t-test analysis between urban and rural schools in terms of availability status of learning facilities

\begin{tabular}{llccccc}
\hline Variable & & $\mathbf{N}$ & $\mathbf{M}$ & SD & t-value & p-value \\
\hline School & Urban & 165 & 15.07 & 3.20 & 1.87 & .062 \\
& Rural & 152 & 14.38 & 3.30 & & \\
\hline
\end{tabular}

As indicated in the above table, the result of an independent sample t-test revealed that the two groups did not differ significantly as $\mathrm{p}>0.05, \mathrm{p}=.062$. The mean for the urban school $(\mathrm{M}=15.07, \mathrm{SD}=3.20)$ was not significantly different than the mean for the rural school $(\mathrm{M}=14.38, \mathrm{SD}=3.30)$. This shows that the availability status of learning facilities for physics curriculum implementation of urban schools and that of rural schools are corresponding.

The data obtained from interviews supports the above results and all respondents said that laboratory equipment, textbooks, reference books, laboratory room and library room are available in all schools although it is not sufficient. And this can be also confirmed via data obtained from document analysis and observation. 
This matching of the availability status of learning facilities in urban and rural schools might be the result of giving due attention to all vicinities by the regional state.

\section{DISCISSIONS, CONCLUSION and RECOMMENDATIONS}

The purpose of this research is to examine the status of learning facilities for primary school physics curriculum implementation in Harari region. İn this research, the findings showed that physics teachers and principals reported that availability status of learning facilities are poor as most of the grand mean of each score was closer to the mid-point (2.0). This result supports previous finding for instance, Solomon and Kedir (2015), revealed that there was inadequate availability of instructional materials in Wolaita and Dawuro Zone secondary schools, similarly Birara (2000), indicated that the existing classrooms have very limited desks, over crowdedness of classrooms and no tables for teachers in Addis Ababa schools. Bekele (2014) also showed that the most important factors affecting science and mathematics education in schools includes insufficient teaching resources, lack of well-equipped laboratories, insufficient time for laboratory activities and large class sizes in Harari Regional State hence, this makes learning milieu inconvenient. In addition to that a study by Tesfamariam et al (2014) revealed that most laboratory rooms available in secondary schools of Mekele town were not built for laboratory purpose and lacked even the most basic facilities like running water, source of electricity; working tables, sinks, hoods and the rooms windows, roofs and doors are broken. Also, another study conducted by Duran-Narucki (2008), concluded that poor facilities lead to poor student attendance, which can result in lower student achievement in examinations. In line with this Bosch (2003), also supported the view that poor school facility can give the negative effect on students' achievement and attendance.

Similarlly, students also reported that availability status of learning facilities are poor as most of the grand mean of each score was closer to the mid-point (2.0). This finding is in agreement with that of Earthman, (2002) and Mc Koy et al. (2008), they said that poor condition of school facilities negatively affects the teachers' performance hence will decrease the academic performance of students in the class. Moreover, the result of an independent sample t-test revealed that the two groups did not differ significantly that is the mean for the urban school was not significantly different than the mean for the rural school. This shows that the availability status of learning facilities for physics curriculum implementation of urban schools and that of rural schools are corresponding.

Hence, based on the findings of the study along with the review of related literature the following conclusions were drawn. Though the adequate availability of learning facilities are vital for effective physics curriculum implementation the availability status of learning facilities are poor and corresponding in urban and rural primary schools of Harari region and it seems reasonable to wind up that the problems would continue unless the conditions in the schools are improved. Therefore, it can be concluded that the inadequacy in availability of learning facilities results in ineffective implementation of primary school physics curriculum. To minimize this problem ministry of education, regional education bureau, woreda education office, nongovernmental organizations, school principals and the community should attempt to provide and fulfill the necessary learning facilities for physics curriculum implementation in the region. Like any other research, this research also has some limitations. That is this study was only conducted only in 17 (7 from urban districts and 10 from rural districts) government primary schools. Therefore, for future research, it is recommended that the results be replicated on a large number of schools which covers private schools also where they also encountered different problems and issues in the curriculum implementation.

\section{REFERENCES}

Akomaye, U., \& Paulina, A. (2017). The impact of educational facilities on students' teaching/learning process in Abeokuta, Ogun state, Nigeria: Need for counselling approaches. European Journal of Education Studies, 3(9), 611-626.

Bandele, S., \& Faremi, Y. (2012). An investigation into the challenges facing the implementation of technical college curriculum in South West, Nigeria. Journal of Education and Practice, 3(12), 8-13.

Bekalo, S., A. \& Welford, A., G. (2000). Practical Activity in Ethiopian Secondary Physical Sciences: Implications for Policy and Practice of the Match between the Intended and Implemented Curriculum. The Ethiopian Journal of Education, 20(2), 91-133.

Bekele, T. (2014). An assessment of challenges and prospects of science and mathematics education in government secondary schools of Harari regional state [Unpublished MA Thesis]. Haramaya University.

Best, J., W. \& Khan, J., V. (2005). Research in education. New Delhi: Pearson. 
Birara, G. (2000). Instructional media in teacher training and in secondary schools in Ethiopia. In D. Bridges \& Marew Zewde (Eds.), Secondary Teacher Education in Ethiopia. Addis Ababa: Addis Ababa University printing press.

Bosch, J. (2003). Identifying relevant variables for understanding how school facilities affect educational outcomes [Unpublished Doctoral Dissertation]. Georgia Institute of Technology.

Dahar, M.A., Dahar, R.A., \& Dahar, R.T. (2009). Mis-allocation of student teacher ratio, class size and per student expenditure leads to the wastage of school resource inputs and lower academic achievement: an issue of resource management. MPRA Paper No. 27835, University Library of Munich, Germany.

Dayo, M., Olushina, O., \& Isaac, A. (2013). Empirical nexus between teaching/learning resources and academic performance in mathematics among pre-university students in Ile-Ife, South-West Nigeria, International Journal of Scientific and Research Publications, 3(3), ISSN 2250-3153.

Donnelly, J. F., \& Jenkins, E. W. (2001). Science education: Policy, professionalism and change. London: Paul Chapman Publishing Ltd.

Duran-Narucki, V. (2008). School building condition, school attendance, and academic achievement in New York City public schools: A mediation model. Journal of Environmental Psychology, 28(3), 278-286.

Earthman, G. I. (2002). School facility conditions and student academic achievement. UCLA: 's Institute for Democracy, Education, and Access. Retrieved from https://escholarship.org/uc/item/5sw56439.

Ethiopian Ministry of Education (2002). The Education and training policy and its implementation. MOE: Addis Ababa.

Gay, L. R., \& Airasian, P. W. (2003). Educational research: Competencies for analysis and application (6th Edition). New Jersey: Prentice Hall.

Kimberly, B., Judi, S., \& Ellen, C. (2009). Mathematics and science in preschool: policy and practice. National Institute for Early Education Research. Rutgers The State University of New Jersey.

McKoy, D., Vincent, J.M., \& Makarewicz, C. (2008). Integrating Infrastructure Planning: The Role of Schools. Access Magazine Journal, 1(33), 18-26.

MOE. (2010). Education sector development program IV. Ministry of Education, AddisAbaba, Ethiopia.

Moochi, O. (2012). Availability, acquisition and Utilisation of instructional resources for teaching Geography in selected secondary schools in Central Kisii District [Unpublished Master's Thesis]. Kenyatta University.

Murungi, C.G., Wambua, M.M., \& Mutwiri, C. (2018). Physical facilities and strategies used by teachers to improve pupils' performance in social studies in Makueni County, Kenya. International Journal of Pregnancy \& Child Birth, 4(6), 241-245.

Negassa, O. (2014). Ethiopian students' achievement challenges in science education: implications to policy formulation. African Journal of Chemical Education, 4(1), 2-18.

Oladejo, M.A, Olosunde, G.R, Ojebisi, A.O., \& Isola, O.M. (2011). Instructional materials and students' academic achievement in physics: some policy implications. European Journal of Humanities and Social Sciences, 2(1), 2220-9425.

Sarantakos, S. (2005). Social research. New York: Palgrave Macmillan.

Solomon, G., G. \& Kedir, O., T. (2015). Problems in the teaching and learning of physics at the secondary and preparatory schools, the cases Wolaita and Dwuro zones. Global Journal of Human-Social Science: $G$ Linguistics \& Education, 15(7), 1-6.

TesfamariamG, Lykknes A, Kvittingen L (2014). Small-scale chemistry for a hands-on approach to chemistry practical work in secondary schools: Experiences from Ethiopia. African Journal of Chemical Education, 4(3), 48-94, Special Issue (Part II).

Tshabalala, T., \& Ncube, C. (2014). Teachers' perceptions on challenges faced by rural secondary schools in the implementation of the technical and vocational education and training policy in Nkayi district. International Research Journal of Teacher Education, 1(2), 10-15.

Umunadi, K. (2012). Resource management and planning in vocational and technical education for national development: An assessment. African Journal of Educational Technology, 2(1), 48-59.

UNESCO (2008). Challenges of implementing free day secondary education in Kenya: Experiences from Districts. Nairobi.

Yadar, K. (2001). Teaching of life science. New Delhi: Anmol publication Ltd, India. 
Yara, P., O. and Otieno, K., O. (2010). Teaching/ learning resources and academic performance in mathematics in secondary schools in Bondo District of Kenya. Canadian Center of Science and Education. Asian Social Science, 6(12), 126-132.

Zhaoyao, M. (2002). Physics education for the 21st Century: Avoiding a Crisis. Physics Education, 37(1), 18-24. 